\title{
USING OF PROPOLIS EXTRACT AS A TRIAL TO EXTEND THE SHELF-LIFE AND IMPROVING THE QUALITY CRITERIA OF FRESH EGYPTIAN SAUSAGE
}

\author{
HANAA H.A. EL-MOSSALAMI ${ }^{*}$ and Y.A. ABDEL-HAKEIM ${ }^{* *}$ \\ *,** Dep. of Food Hygiene, Animal Health Research Institute / Alex. Branch. \\ Email: elmoslamyh@yahoo.com
}

\section{ABSTRACT}

Received at: $12 / 8 / 2013$

This work was planned to evaluate the effect of propolis on the different quality criteria of fresh Egyptian sausage as well as its shelf life. Three groups of processed fresh beef Egyptian sausage were used the first two groups were treated with 400

Accepted: 7/10/2013 and $600 \mathrm{mg}$ ethanolic extract of propolis (EEP) $/ \mathrm{Kg}$, respectively the third group left as a control was kept at $5^{\circ} \mathrm{C}$. All groups were examined every 3 days untill the signs of spoilage were detected. All groups were investigated for sensory, chemical and microbiological deteriorative criteria. The results revealed that control samples were decomposed after 12 days, while the of treated samples showed longer shelf life, as it decomposed after 21 days. Thiobarbituric Acid (TBA-value) mg mal/ kg, and Total Volatil Bases Nitrogen (TVB-N) mg/ 100g were gradually increased in all examined samples, with lower level for treated samples than control one. Also gradual increase in microbiological load of control samples throughout the storage time was observed, whereas, proteolytic, lipolytic and total mould and yeast counts were $6.38 \pm 0.40,5.99 \pm 0.56$ and $6.59 \pm 0.52 \log _{10} \mathrm{cfu} / \mathrm{g}$, respectively at the 12 th day and rejected. Such counts were slightly decreased in treated samples up to 15 th day of storage, for treated group one samples $(400 \mathrm{mg}$ ethanolic extract of propolis $(\mathrm{EEP}) / \mathrm{Kg}$ ) were $5.36 \pm 0.18,4.98 \pm 0.52$ and $4.80 \pm 0.35 \log _{10} \mathrm{cfu} / \mathrm{g}$, respectively. Such counts were significantly decreased in treated group two samples $(600 \mathrm{mg}$ ethanolic extract of propolis $(\mathrm{EEP}) / \mathrm{Kg}$ ) were $3.46 \pm 0.22,2.89 \pm 0.20$ and $3.59 \pm$ 0.34 , respectively, followed by gradual increase till the end of storage time. The results have proved to be satisfactory, as the propolis had not adversely affected the quality characteristics and was efficient in controlling the lipid oxidation microbial effects in the final products. Finally propolis is recommended as a preservative in fresh sausage processing.

Key words: Propolis Extract, Sausage, Shelf-life

\section{INTRODUCTION}

Bee glue called propolis is a dark sticky resinous substance collected by bees from leaf buds, twigs, trunk wounds, and trees such as Castanea sativa, Populus spp., and Aesculus hippocastanum. Bees attach the propolis to their hind legs, and carry it back to their colony, where it is combined with bees wax and used by worker "hive" bees to seal and sterilize the colony nest (Greenaway et al., 1990; Sorkun et al., 2001). Propolis contains a varity of chemical compounds such as polyphenols (flavonoid aglycones, phenolic acids, and their esters, phenolic aldehydes and alcohols), terpenoids, steroids, amino acids, and inorganic compounds (Kartal et al., 2003; Naydenski et al., 2010).

Propolis has been used in folk medicine to maintain health since ancient times (Isla et al., 2001). Many biological properties including antibacterial, antifungal, antiviral, local anesthetic, antiinflammatory, antioxidant, hepatoprotective, immunostimulate and cytostatic activities have been ascribed to propolis. Therefore, propolis is available commercialy in different formulated forms such as tablets, capsules, toothpaste, mouthwash preparations, face creams, ointments, lotions, and solutions (Kartal et al., 2003; DeCastro and Higashi, 1995). The medical applications of propolis have led to increased interest in its chemical composition as well as its origin (Bankova et al., 1989; Popova et al., 2001).

In fact, it is known that plants are rich in a wide variety of secondary metabolites such as tannins, terpenoids, alkaloids, and flavonoids, which are found in vitro to have antimicrobial properties (Pahsa et al., 2009). The antimicrobial activity of propolis against a wide range of bacteria, fungi, and viruses has been investigated since the late 1940s and it showed variable activity against different microorganisms (Hegazi, 2000; Uzel et al., 2005). Many researchers 
have studied the antibacterial activity of propolis and its extract against gram-positive and gram-negative bacteria. They found that propolis had antibacterial activity against a wide range of gram-positive strains but had limited or no activity against gram-negative strains (Grange and Davey, 1990; Dobrowolski et al., 1991; Marcucci, 1995; Sforcin et al., 2000; Kartal et al., 2003; Cihangiret al.,2005; Uzel et al., 2005).

In the context of the lack acceptability of synthetic preservatives, there is a growing interest of introducing natural additives to food. Propolis is an interesting alternative to be considered in new applications of food technology as it is extensively used, as phytochemical ingredient, in functional foods at levels that may confer health benefits (International Food Information Service, 2005). Propolis chemical composition is complex and varies according to its botanical and phytogeographical origin, but in general, propolis in nature is composed of $30 \%$ wax, $50 \%$ resin and vegetable balsam, $10 \%$ essential and aromatic oils, 5\% pollens and 5\% various other substances, including organic debris (Greenaway et al., 1991; Bonvehi et al., 1994; Burdock, 1998; Bankova and Marcucci, 2000; Kalogeropoulos et al., 2009; Petrova et al., 2010).

The antibacterial, antifungal and antioxidant properties of propolis are combined with the fact that several of its constituents present in food and/or food additives, and Generally Recognized As Safe (GRAS) (Burdock, 1998 and Costa Campos et al., 2011), make it an attractive candidate as a natural preservative in new food applications. This meets the demand for natural antioxidants and antimicrobials, fueled by the increasing consumer awareness for natural, minimally processed foods with traditional preservatives absent or at very low concentrations (Han and Park, 1995; Tosi et al., 2007). Kilic et al., 2005; Raghukumar et al., 2010) documented the antimicrobial activity of propolis extract against Methicillin-Resistant Stapylococcus aureus (MRSA). Moreover, Propolis displayed both bacteriostatic and bactericidal actions depending on the concentration, type of propolis, and type of bacteria tested (Assegid et al., 2004; Temiz et al., 2011; El-Bassiony et al., 2012).

Fresh sausage is one of the most popular furthered processed meat products. It is formulated from a combination of raw ingredients which yield a final product of acceptable quality and competitive price. Moreover, the high microbiological quality is necessary to improve the processed meat products (Nouman et al., 1982).

The oxidative rancidity of fats during storage of meat and meat products causes the development of objectionable odour and flavor and may also give rise to deleterious nutritional effects, as destruction of essential fatty acids and vitamins. Moreover, free radicals produced during oxidation process are considered recently as carcinogenic substances (Trusheva et al., 2006). The rate and extent of oxidative deterioration can be reduced by various means such as curing to preserve the meat tissues, vacuum packaging to remove the oxygen source, or adding antioxidants to scavenge the oxidants (Wong et al., 1995). The author further added that application of antioxidants is one of the simplest ways of reducing lipid oxidation. As addition of antioxidant minimize lipid peroxidation, through act as oxygen scavengers, react with free radicals and chelate catalytic metals and thus retard oxidative deterioration (Shahidi and Wanasundara, 1992).

It's worth mentioning that propolis can be used as water or ethanolic extract, both extracts can reduce the total volatile basic nitrogen content in fresh sausage and so can serve as a good preservative and can contribute to promote human health because they are naturally produced (Han et al., 2001). However, propolis water extracted had the weakest antibacterial, antioxidant and antifungal action than ethanolic extract (Assegid et al., 2004). In recent years, propolis has been taken for health reasons with limited use in meat processing and food preservation. This work was under taken to evaluate the potentials of ethanolic extract of propolis as decontaminants and antioxidant for fresh Egyptian sausage during refrigerated storage and to estimate the possibility of the usage of propolis to increase shelf life of fresh Egyptian sausage.

\section{MATERIALS and METHODS}

Purification of propolis: Crude propolis (honey bee glue) samples were obtained from the Departement of Food Technology at the Faculty of Agriculture, Alexandria University. Propolis samples were manually purified from impurities (wood, straw, fragments and insects), then blended to fine particles in a waring blender and stored in a dark bottle at room temperature until use (Bonvehi et al., 1994; Said et al., 2006 and Haddadin et al., 2008).

Extraction of propolis: Propolis samples were extracted according to the method described by Han and Park, (2002) and Biscaia and Ferreira, (2009). Five $g$ of propolis were placed inside a paper thimble and submitted to Soxhlet extraction at a maximum temperature of $60^{\circ} \mathrm{C}$ for $6 \mathrm{~h}$, using $150 \mathrm{ml}$ of solvent (ethanol). Waxes from extracted were removed by 3 consecutive steps of maintaining at $-18^{\circ} \mathrm{C}$ overnight and filteration at $0^{\circ} \mathrm{C}$. The resulting extracts were evaporated at reduced pressure at a low temperature $\left(<40^{\circ} \mathrm{C}\right)$ in a rotary evaporator to afford a concentrated ethanolic extract of propolis (EEP). The 
extract was transferred to small glass vials with a small amount of methanol which evaporated. Different concentrations were prepared (100, 200, $400,600,800$, and $1000 \mathrm{mg} / \mathrm{L}$ ) by dissolving the final Ethanol Extract Propolis (EEP) in distillated water to determine the minimum inhibitory concentration (MIC).

Estimation of MIC of EEP: Estimation ofMIC was performed according to method (disk diffusion method) prescribed by (Silva et al., 2008). MIC was determined using agar disk diffusion method (150 $\mathrm{mg} / \mathrm{L})$.

Sausage manufacture: Fresh Egyptian sausage was processed according to the quality criteria recommended by the Egyptian Organization for Standardization and Quality Control (ESS, 1991), where the formula used is as follows: Fresh lean meat $(7 \mathrm{~kg})$, beef fat $(1.5 \mathrm{~kg})$, soy hydrate $(0.3 \mathrm{~kg})$, skimmed milk $(0.15 \mathrm{~kg})$, bread $(0.2 \mathrm{~kg})$, water $(1 \mathrm{~kg})$, sodium chloride $(0.2 \mathrm{~kg})$ and black pepper $(0.035 \mathrm{~kg})$.
Fresh beef and fat were minced, and other ingredients were added thereafter. The past obtained was divided into three portions, the first was stuffed in natural mutton casing as control samples, the second portion was treated with $400 \mathrm{mg} \mathrm{EEP} / \mathrm{kg}$ and the third portion was treated with $600 \mathrm{mg} \mathrm{EEP} / \mathrm{kg}$, which stuffed in the same manner as the control samples. All control and treated samples were then packed in polyethylene bags and chilled in a refrigerator at $5^{\circ} \mathrm{C}$. During refrigerated storage, the control and treated samples were examined every three days for sensory, chemical and microbiological deteriorative criteria until spoilage occurred as described below:

Sensory evaluation: Sensory attributes for raw and cooked sausage sample (form, binding, colour, odour and taste) were examined according to the scheme adopted by (Mohamed Manal, 2002) and are shown in Table I. Sensory examinations of samples were conducted by an untrained independent panel consisting of 10 members from the Food Hygiene Departement until the end of the study.

Scheme used for sensory evaluation of fresh sausage:

\begin{tabular}{lll}
\hline Sensory attributes & Desirable & Undesirable \\
\hline Form & Normal & Deformed and burst casing \\
\hline Binding & Firm & Poor \\
\hline Colour & Bright red, dark red & Brown, grey \\
\hline Odour & Fresh, spicy & Rancid, putrid \\
\hline Taste & Fleshy & Bitter and decomposed \\
\hline
\end{tabular}

\section{Chemical examination:}

\section{A- Determination of Total Volatile Bases Nitrogen (TVB-N):}

Using the distillation method was performed as recommended by (Harold et al., 1981) as follow: Hundred gram of prepared sample was weighed into a homogenizer with $30 \mathrm{ml}$ of $5 \%$ trichloroacetic acid to obtain uniform slurry, then filtered and centrifuged to obtained a clear extract. Five $\mathrm{ml}$ of the extract was transferred to a semimicro distillation apparatus. Five $\mathrm{ml} 2 \mathrm{M}$ sodium hydroxide solution was added then distilled (steam distillation). The distillate was collected in $15 \mathrm{ml} 0.01 \mathrm{M}$ standard hydrochloric acid. Rosolic acid solution was used as indicator $(1 \%$ resolic acid in $10 \%$ ethanol $\mathrm{v} / \mathrm{v})$, and then titrated with $0.01 \mathrm{~N}$ sodium hydroxide to a pale pink colorend point with 0.01 sodium hydroxide.

\section{Calculation:}

Total Volatile Bases Nitrogen $=14(300+w) \times \mathrm{v} / 500 \mathrm{mg} / \mathbf{1 0 0 g}$

Where: $\mathbf{V}=$ volume of Standard Acid Consumed in the Titration

$\mathbf{W}=$ Water Content of the Sample as $\mathrm{mg} / 100 \mathrm{~g}$.

\section{B- Determination of the Thiobarbituric acid (TBA) value:}

Using the distillation method was applied according to a technique described by the Food and Agriculture Organization (FAO, 1986). The TBA values were expressed as mg-malondialdehyde $/ \mathrm{kg}$.

\section{Microbiological examination:}

Sample homogenate was prepared by homogenization of $10 \mathrm{~g}$ of examined sample with $90 \mathrm{ml}$ sterile peptone water $0.1 \%$. From sausage homogenate, sterial decimal dilutions up to $10^{8}$ were performed. The microbiological procedures recommended by the American Public Health Association (APHA, 1992) were applied as follows: 


\section{Assiut Vet Med .J.Vol 59 No. 139 October 2013}

- The proteolytic count was performed using Skimmed milk agar 10\% (Oxoid, CML 31).

- Lipolytic count on Tributyrine agar (Oxoid, PM4).

- Total mould and yeast count on Sabouraud dextrose agar (Oxoid, CM41).

Statistical analysis: The obtained data was analyzed statistically according to (Perrie and Waston, 1999). The results are presented as the mean of three replicates. The analytical test used included unpaired Student t-test to compare means for two groups at $\mathrm{p}<0.05$.

\section{RESULTS}

Table 1: Sensory evaluation of control and treated sausage samples during refrigerated storage.

\begin{tabular}{llll}
\hline Parameters & Treatment with EEP & Desirable & Undesirable \\
\hline Control & untreated & Days $0-11$ & Days 12 \\
\hline Group 1 & Treated with $400 \mathrm{mg} / \mathrm{kg}$ & Days $0-17$ & Days 18 \\
\hline Group 2 & Treated with $600 \mathrm{mg} / \mathrm{kg}$ & Days $0-20$ & Days 21 \\
\hline
\end{tabular}

Table 2: TVB-N mg/100g and Thiobarbituric acid value TBA mg-malondialdhyde/kg in control and treated sausage samples during refrigerated storage.

\begin{tabular}{ccccccc}
\hline Time / day & \multicolumn{3}{c}{ TBA - value } & \multicolumn{3}{c}{ TVB $-\mathrm{N}$} \\
\cline { 2 - 7 } & Control & Group1 & Group2 & Control & Group1 & Group2 \\
\hline Zero time & & $0.22 \pm 0.018$ & & & $9.7 \pm 0.50$ & \\
\hline $3^{\text {rd }}$ day & $0.28 \pm 0.011$ & $0.27 \pm 0.020$ & $0.27 \pm 0.010$ & $10.3 \pm 0.70$ & $10.2 \pm 0.40$ & $10.1 \pm 0.63$ \\
\hline $6^{\text {th }}$ day & $0.37 \pm 0.021$ & $0.32 \pm 0.040$ & $0.30 \pm 0.010$ & $12.8 \pm 0.90$ & $11.8 \pm 0.70$ & $11.1 \pm 0.86$ \\
\hline $9^{\text {th }}$ day & $0.55 \pm 0.030$ & $0.46 \pm 0.010$ & $0.41 \pm 0.020$ & $* 16.1 \pm 1.10$ & $14.2 \pm 0.60$ & $12.1 \pm 0.84$ \\
\hline $12^{\text {th }}$ day & $* 0.73 \pm 0.042$ & $0.61 \pm 0.050$ & $0.57 \pm 0.031$ & $* 19.7 \pm 1.51$ & $15.3 \pm 0.50$ & $12.3 \pm 0.75$ \\
\hline $15^{\text {th }}$ day & & $0.74 \pm 0.030$ & $0.68 \pm 0.020$ & & $17.2 \pm 0.90$ & $14.5 \pm 1.05$ \\
\hline $18^{\text {th }}$ day & & $0.86 \pm 0.013$ & $0.79 \pm 0.040$ & & $19.1 \pm 0.75$ & $16.7 \pm 1.30$ \\
\hline $21^{\text {th }}$ day & & & $0.88 \pm 0.050$ & & & $19.2 \pm 0.85$ \\
\hline
\end{tabular}

*Means significant differences between the control and treated samples at $\mathrm{P}<0.05$

Table 3: Mean values of Proteolytic, Lipolytic and total Mould and Yeast count $\log _{10} \mathrm{cfu} / \mathrm{g}$ of control and treated sausage samples during refrigerated storage.

\begin{tabular}{|c|c|c|c|c|c|c|c|c|c|}
\hline \multirow[t]{2}{*}{ Time /day } & \multicolumn{3}{|c|}{ Proteolytic } & \multicolumn{3}{|c|}{ Lipolytic } & \multicolumn{3}{|c|}{ Mould\& Yeast } \\
\hline & Control & Group1 & Group2 & Control & Group1 & Group2 & Control & Group1 & Group2 \\
\hline Zero time & \multicolumn{3}{|c|}{$3.76 \pm 0.12$} & \multicolumn{3}{|c|}{$2.99 \pm 0.23$} & \multicolumn{3}{|c|}{$3.98 \pm 0.30$} \\
\hline $3^{\text {rd }}$ day & $\begin{array}{c}3.76 \pm \\
0.25\end{array}$ & $\begin{array}{c}3.46 \pm \\
0.30\end{array}$ & $\begin{array}{c}3.29 \pm \\
0.27\end{array}$ & $\begin{array}{c}3.29 \pm \\
0.31\end{array}$ & $\begin{array}{c}2.98 \pm \\
0.18\end{array}$ & $\begin{array}{c}2.94 \pm \\
0.18\end{array}$ & $\begin{array}{c}3.94 \pm \\
0.36\end{array}$ & $\begin{array}{c}3.48 \pm \\
0.26\end{array}$ & $\begin{array}{c}3.46 \pm \\
0.23\end{array}$ \\
\hline $6^{\text {th }}$ day & $\begin{array}{c}3.99 \pm \\
0.35\end{array}$ & $\begin{array}{c}3.55 \pm \\
0.26\end{array}$ & $\begin{array}{c}3.29 \pm \\
0.26\end{array}$ & $\begin{array}{c}3.94 \pm \\
0.32\end{array}$ & $\begin{array}{c}3.12 \pm \\
0.14\end{array}$ & $\begin{array}{c}2.89 \pm \\
0.13\end{array}$ & $\begin{array}{c}4.29 \pm \\
0.40\end{array}$ & $\begin{array}{c}3.56 \pm \\
0.32\end{array}$ & $\begin{array}{c}3.46 \pm \\
0.27\end{array}$ \\
\hline $9^{\text {th }}$ day & $\begin{array}{c}4.46 \pm \\
0.35\end{array}$ & $\begin{array}{c}3.99 \pm \\
0.41\end{array}$ & $\begin{array}{c}3.68 \pm \\
0.30\end{array}$ & $\begin{array}{c}3.99 \pm \\
0.26\end{array}$ & $\begin{array}{c}3.68 \pm \\
0.30\end{array}$ & $\begin{array}{c}2.99 \pm \\
0.24\end{array}$ & $\begin{array}{c}4.68 \pm \\
0.41\end{array}$ & $\begin{array}{c}3.98 \pm \\
0.25\end{array}$ & $\begin{array}{c}3.89 \pm \\
0.31\end{array}$ \\
\hline $12^{\text {th }}$ day & $\begin{array}{c}* 6.38 \pm \\
0.40 \\
\end{array}$ & $\begin{array}{c}.76 \pm \\
0.35\end{array}$ & $\begin{array}{c}3.46 \pm \\
0.20 \\
\end{array}$ & $\begin{array}{c}* 5.99 \pm \\
0.56 \\
\end{array}$ & $\begin{array}{c}3.76 \pm \\
0.27 \\
\end{array}$ & $\begin{array}{c}2.76 \pm \\
0.18\end{array}$ & $\begin{array}{c}* 6.59 \pm \\
0.52\end{array}$ & $\begin{array}{c}4.28 \pm \\
0.46 \\
\end{array}$ & $\begin{array}{c}3.46 \pm \\
0.32 \\
\end{array}$ \\
\hline $15^{\text {th }}$ day & & $\begin{array}{c}5.36 \pm \\
0.18\end{array}$ & $\begin{array}{c}3.46 \pm \\
0.22\end{array}$ & & $\begin{array}{c}4.98 \pm \\
0.52\end{array}$ & $\begin{array}{c}2.89 \pm \\
0.20\end{array}$ & & $\begin{array}{c}4.80 \pm \\
0.35\end{array}$ & $\begin{array}{c}3.59 \pm \\
0.34\end{array}$ \\
\hline $18^{\text {th }}$ day & & $\begin{array}{c}6.12 \pm \\
0.46\end{array}$ & $\begin{array}{c}3.99 \pm \\
0.32\end{array}$ & & $\begin{array}{c}5.41 \pm \\
0.55\end{array}$ & $\begin{array}{c}3.59 \pm \\
0.28\end{array}$ & & $\begin{array}{c}5.75 \pm \\
0.52\end{array}$ & $\begin{array}{c}3.99 \pm \\
0.36\end{array}$ \\
\hline $21^{\text {th }}$ day & & & $\begin{array}{c}6.46 \pm \\
0.41\end{array}$ & & & $\begin{array}{c}3.99 \pm \\
0.26\end{array}$ & & & $\begin{array}{c}5.99 \pm \\
0.55\end{array}$ \\
\hline
\end{tabular}

*Means significant differences between the control and treated samples at $\mathrm{P}<0.05$ 


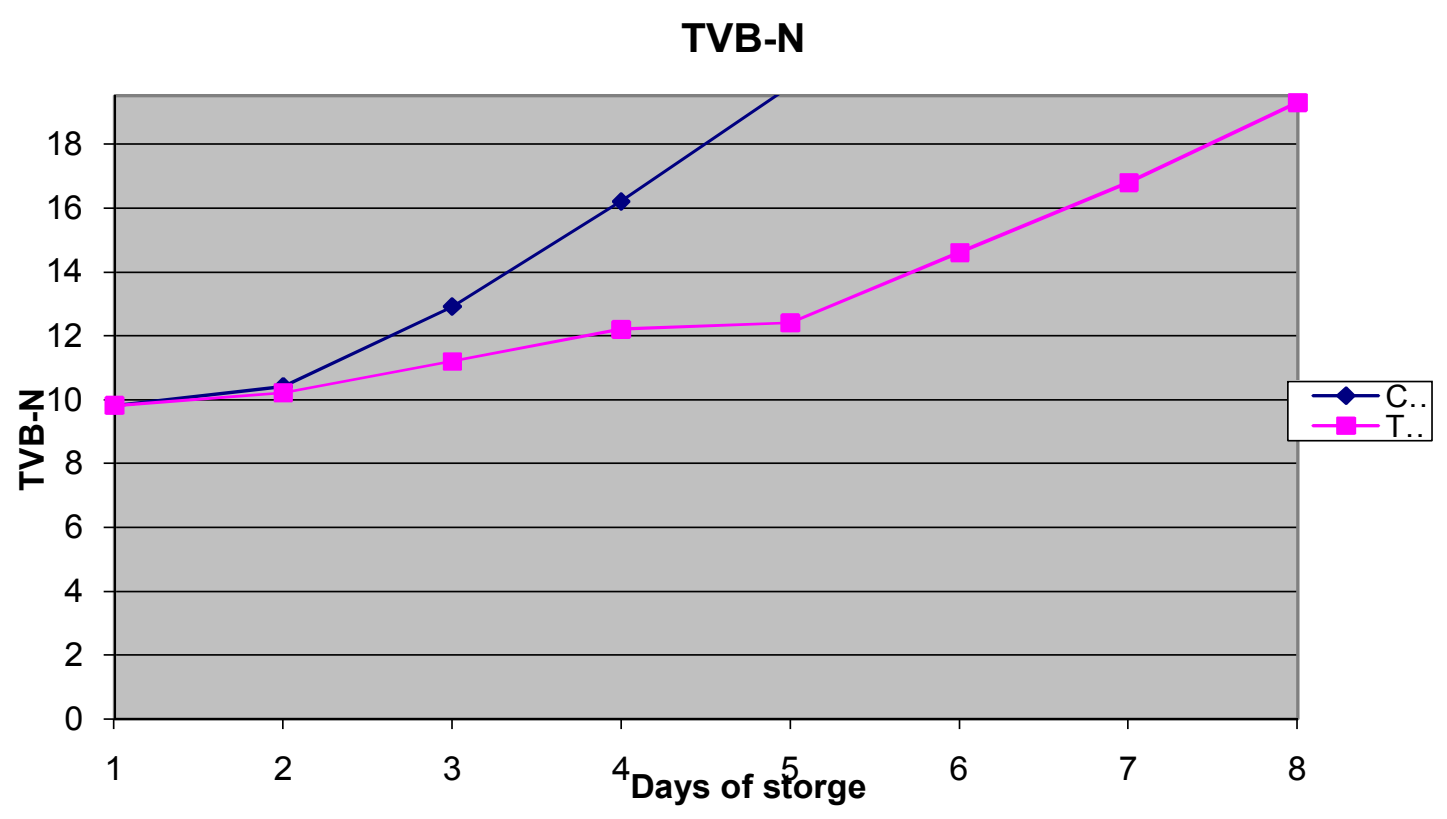

Fig. (1): TVB-N mg/100g in control and treated sausage samples during refrigerated storage.

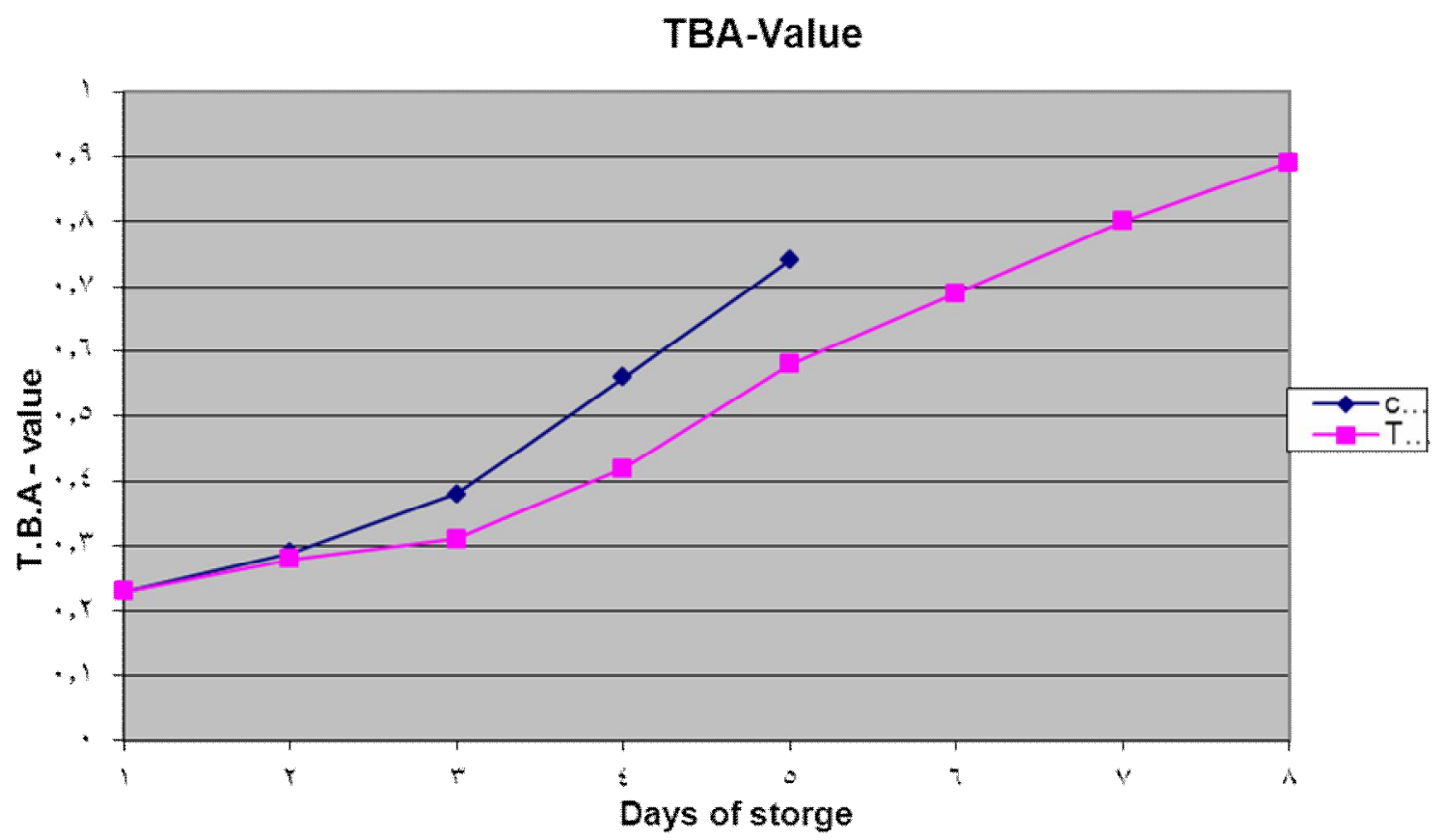

Fig. (2): Thiobarbituric acid value TBA mg- malondialdhyde/kg in control and treated sausage samples during refrigerated storage. 


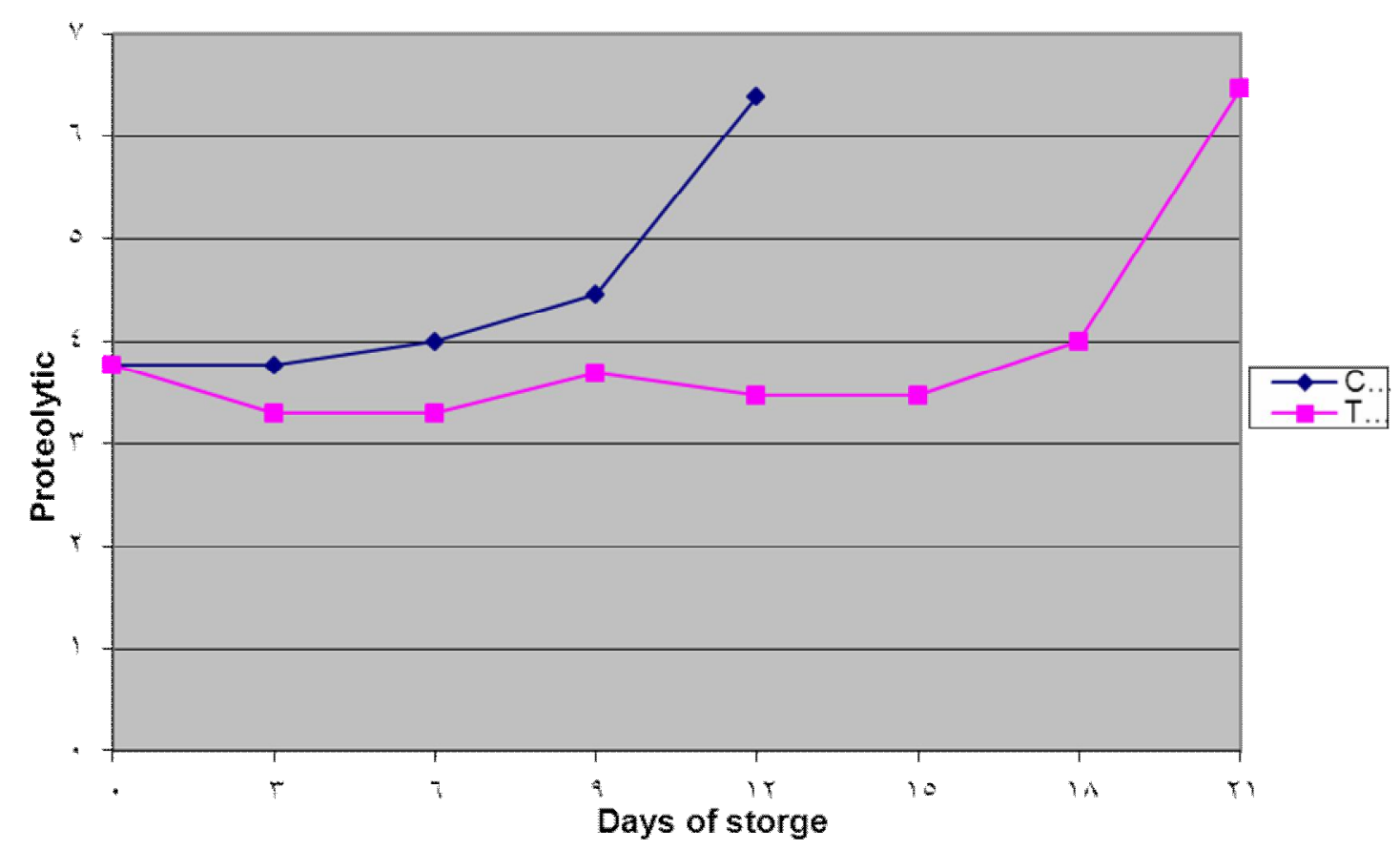

Fig. (3): Mean values of Proteolytic count $\log _{10} \mathrm{cfu} / \mathrm{g}$ of control and treated sausage samples during refrigerated storage.

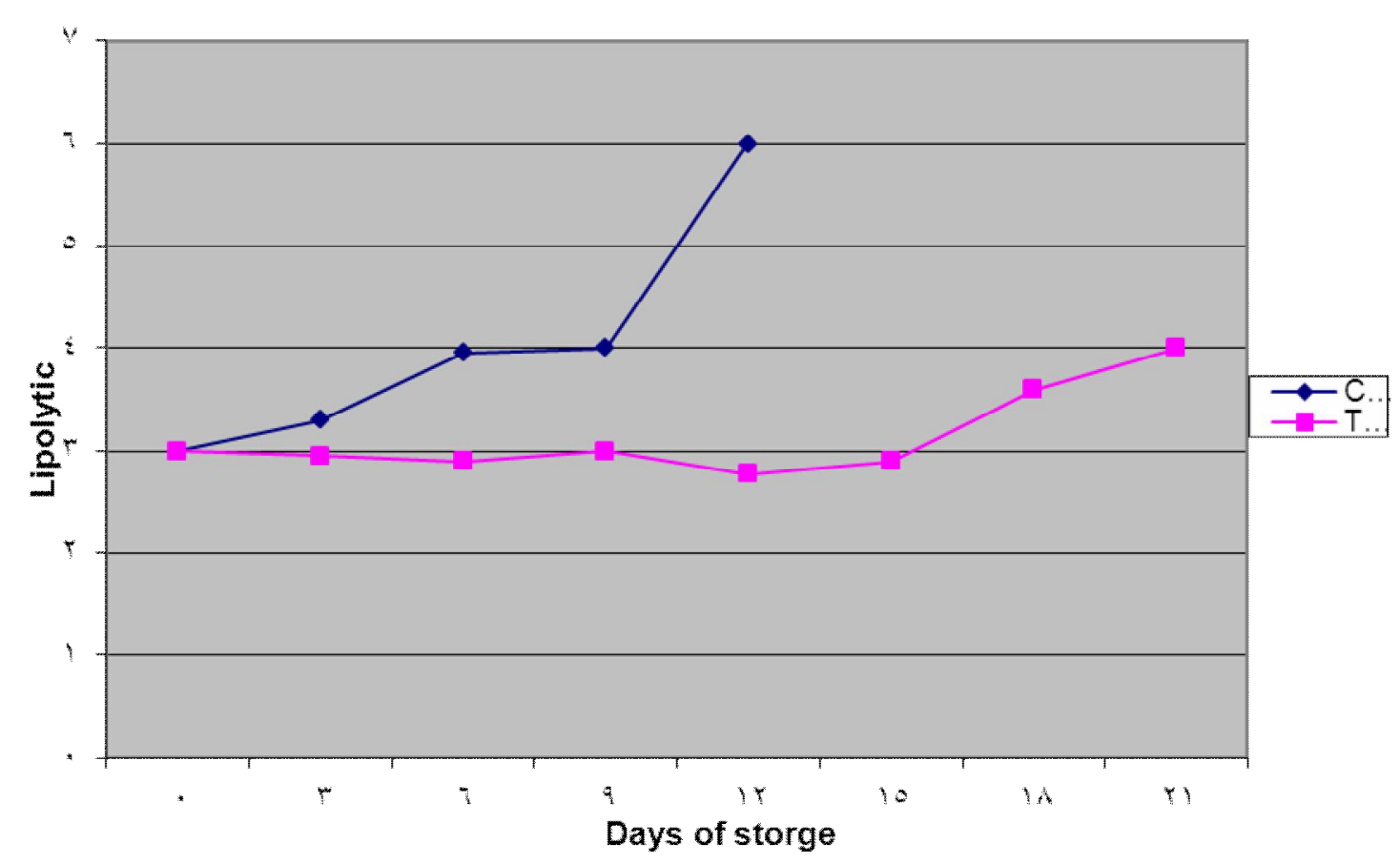

Fig. (4): Mean values of Lipolytic count $\log _{10} \mathrm{cfu} / \mathrm{g}$ of control and treated sausage samples during refrigerated storage. 


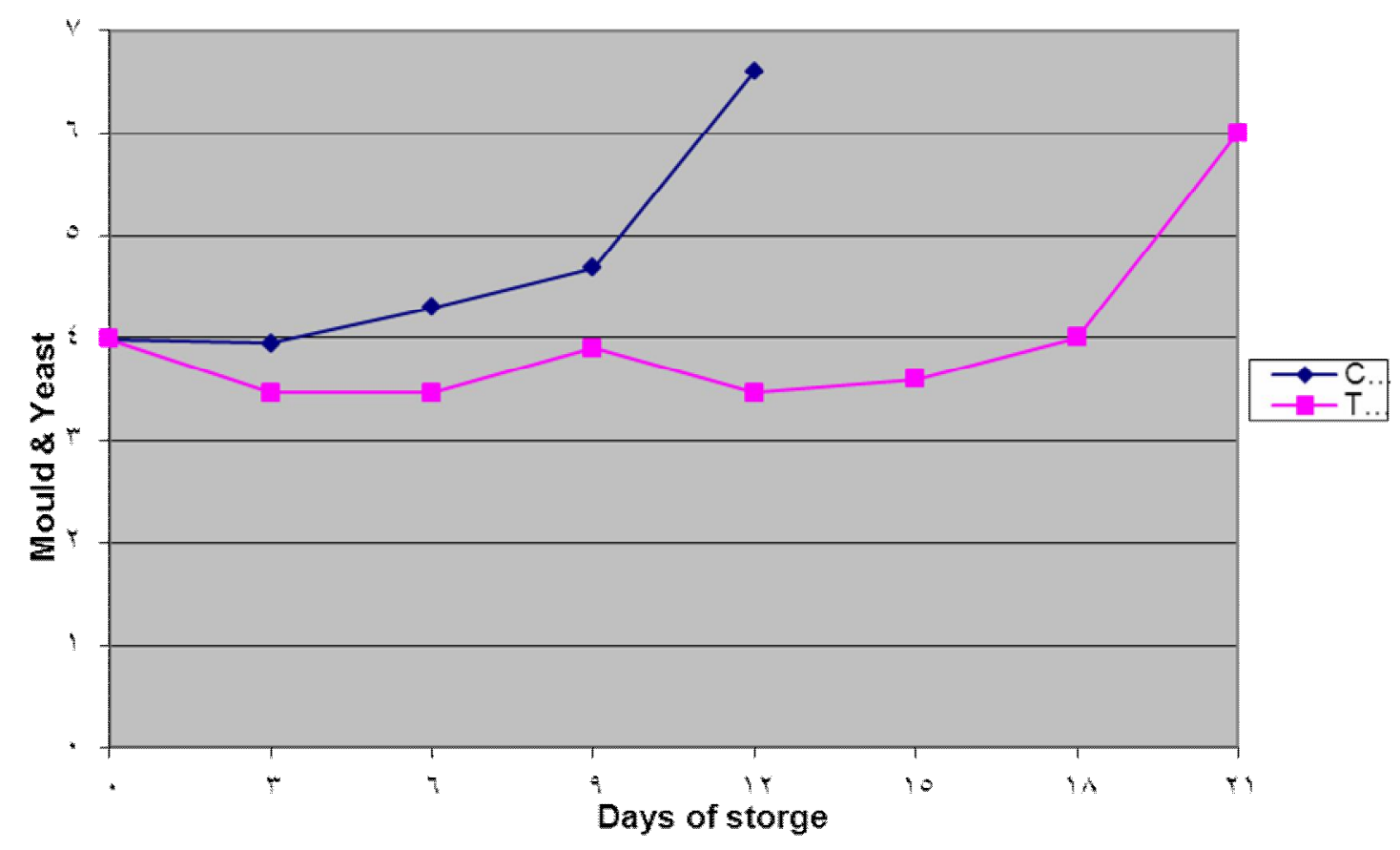

Fig. (5): Mean values of total Mould and Yeast count $\log _{10} \mathrm{cfu} / \mathrm{g}$ control and treated sausage samples during refrigerated storage.

\section{DISCUSSION}

Bees use propolis as a protective barrier against intruders by sealing holes in their honeycombes (Burdock, 1998; Salatino et al., 2005; Sforcin, 2007). Moreover, propolis is responsible for the low incidence of bacteria and moulds within the hive as it has antibacterial and antifungal properties (Bankova et al., 2000). The antimicrobial effect of propolis is due to its components that are mostly of phenolic nature, mainly flavonoids, as the simple phenols, phenolic acids and polyphenols are active antimicrobial agents (Cowan, 1999; Temiz et al., 2011). Propolis has been used a popular remedy in folk medicine, in apitherapy, as a constituent of biocosmetics, health foods and in numerous other purposes (Bankova et al., 2000; Banskota et al., 2001; El-Bassiony et al., 2012).

From data in Table 1 presents sensory acceptance of control samples as highly desirable for the first six days and for the following five days, samples became just desirable, while on day 12 of storage, spoilage signs (offensive odour, unpleasant taste and formation of a greenish colour) were clear and the samples were discarded. Treated samples were accepted by the team of panelists for six and nine days more than control samples and were reject after $18 \& 21$ days of storage, respectively. These results concurred with those obtained by Hemeida and Kobeassy (2002) and Hašcik et al. (2011).
In regard to the deteriorative criteria of chemicals, the TBAvalue was determined as an index of lipid oxidation taking place in sausage samples during refrigerated storage. The results in Table 2 and Figs $1 \& 2$ reveals that the TBA value mgmalondialdehyde $/ \mathrm{kg}$ was subjected to a gradual increase during the experimental period. In addition, TBA values in control samples were the highest in comparison to treated samples $(400 \& 600 \mathrm{mg}$ EEP $/ \mathrm{kg}$ ). On day12 of storage, the TBA value in the control samples was $0.73 \pm 0.042$. This value was slightly below the rejection limit $(0.9 \mathrm{mg}$ malondialdehyde $/ \mathrm{kg}$ ) stipulated by the EES (1991) and correlated well with sensory attributes (poor colour and taste), the control samples were therefore rejected. A significantly $(\mathrm{p}<0.05)$ lower value $(0.57 \pm$ 0.031 ) was recorded in treated samples (group 2).On day18 of storage, the TBA value in the treated group1 samples was $0.86 \pm 0.013$ while, on day 21 of storage the TBA value in the treated group 2 samples was $0.88 \pm 0.050$. This values was slightly below the rejection limit.The data we obtained were very similar to those obtained by Han and Park (2002); Hemeida and Kobeassy (2002).

The addition of ethanolic extract of propolis $(400 \&$ $600 \mathrm{mg} \mathrm{EEP} / \mathrm{kg}$ ) to sausage samples significantly $(p<0.05)$ retarded the oxidative changes of lipid oxidation may be related to its content of flavonoids and phenolic compounds (Dessouki et al., 1980; 
Marcucci, 1995; Hayashi et al., 1999; Hegazi and Abd El-Hady, 2002; Be-Jen et al., 2003; Nagai et al., 2003; Marquele et al., 2006; Contreras-Castillo et al., 2009). In addition, its antibacterial effect against lipolytic bacteria may enhance antioxidant properties.

TVB-N mg/100g content Table 2 for the control samples $(19.7 \pm 1.51)$ on day 12 of refrigerated storage is the highest value obtained, while treated (400 \& 600mg EEP/kg) samples showed a significantly $(p<0.05)$ lower level than those of the corresponding control samples on days 9 and 12 of storage and did not exceed the permissible limit of 20 $\mathrm{mg} / 100 \mathrm{~g}$ stipulated by the EES (1991). On day18 of storage, theTVB-N mg/100g content in the treated group1 samples was $19.1 \pm 0.75$ while, on day 21 of storage theTVB-N mg/100g content in the treated group 2 samples was $19.2 \pm 0.85$. This values did not exceed the permissible limit. This could be attributed to the preservative action of propolis on proteolytic bacteria. These results agree with those obtained by (Han et al., 2001; Hemeida and Kobeassy, 2002).

TVB-N is considered to be an important factor when measuring the extent of protein degradation to amino acids and purification of meat and meat products (Han et al., 2001), it is also considered to be an index of deterioration in regard to the sourness of sausages (Olivant, 1957). In this respect, Abd El-Salam (1978) started that TVB-N content was found to increase in frozen meat during storage, which lowered the shelflife of sausages prepared from frozen meat.

Recently, consumers think that the natural food preservatives are better and safer than synthetic ones as they are considered the reason of many carcinogenic and teratogenic attributes as well as residual toxicity. The investigation of natural sources, which offer an unique pool of chemically diverse substances, is a valid approach to the search for new antimicrobials with chemical scaffolds that differ from known antibiotics would have less tendency to generate microbial resistance and health problems. In the last decades, propolis has gained wide acceptance by people from many western and eastern countries (Temiz et al., 2011; El-Bassiony et al., 2012).

Results in Table 3 and Figs 3,4\&5 reveals that no change in the mean proteolytic, lipolytic and total mould and yeast counts in control samples for the first 3 days of refrigerated storage. However, a gradual increase in the organisms examined had been observed through out the storage period and signs of spoilage began to appear on day 9. Finally, on day 12, significantly higher counts of proteolytic, lipolytic and total mould and yeast $(6.38 \pm 0.40,5.99 \pm 0.56$ and $6.59 \pm 0.52 \log _{10} \mathrm{cfu} / \mathrm{g}$, respectively) were noted and signs of spoilage were more pronounced, the samples were rejected. On the contrary, Table 3 shows a decrease in microbial load of treated samples during refrigerated storage till days 15 as proteolytic, lipolytic and total mould and yeast counts were 5.38 $\pm 0.18,4.98 \pm 0.52$ and $4.80 \pm 0.35$ for group 1 and $3.46 \pm 0.22,2.8 \pm 0.20$ and $3.5 \pm 0.34 \log _{10} \mathrm{cfu} / \mathrm{g}$ for group 2, respectively, followed by a gradual increase on days 18 of group 1 storage to be $6.12 \pm 0.46,5.41 \pm$ 0.55 and $5.75 \pm 0.52 \log _{10} \mathrm{cfu} /$ gand on days 21 of group 2 storage to be6.46 $\pm 0.41,3.99 \pm 0.26$ and $5.99 \pm 0.55 \log _{10} \mathrm{cfu} / \mathrm{g}$ for proteolytic, lipolytic and total mould and yeast counts, respectively, and the samples were rejected on day $18 \& 21$ of storage. The results obtained agreed with those recorded by (Hemeida and Kobeassy, 2002).

(Cihangir et al., 2005) determined the minimal inhibitory concentration (MIC) of ethanol extract of the propolis samples collected from different regions of Turkey against 3 gram- positive ( $S$. aureus, B. subtilis, and a $\beta$ - hemolytic Streptococcuc sp.) and 3 gram-negative (E. coli, Salmonella typhi, and a proteus sp.) bacterial strains. The MIC values of EEP samples for gram-negative bacteria were higher than those of gram-positive bacteria 10 to 100 times depending on the regions of EEP samples.

The data obtained during this study indicated that the treated samples (400 \& $600 \mathrm{mg} \mathrm{EEP} / \mathrm{kg})$ had a longer shelf-life than the control sample, this confirmed the reports of (Ashour, 1989; El- Deib et al., 1997; Hegazi and Abd El-Hady, 2001, 2002; Hemeida and Kobeassy, 2002; Lu et al., 2005; Said et al., 2006; Trusheva et al., 2006; Ali et al., 2010 and Rodriguez Vaquero et al., 2011), namely, that propolis has antibacterial and antifungal properties and that propolis obtained from different sources has different antibacterial and antifungal effects.

\section{CONCLUSION}

Antibacterial activity of propolis depends on the chemical composition and especially the concentration of the components and compounds of the samples. These findings confirm that the antibacterial activity of propolis may be attributed to the synergism between flavonoids and other components and compounds of EEP samples. This study offers useful information for the usage of propolis as a natural antimicrobial agent to control microbial growth in food products and might provide an alternative to chemical preservatives.

Propolis is considered to be a good decontaminant and antioxidant as it reduces the microbial load, lowered TVB-N content and TBA value and improved the sensory quality of fresh sausage. Finally, it also extended the shelf-life of the experimentally formulated Egyptian sausage. Consequently, propolis is recommended as a natural 
decontaminant and antioxidant in Egyptian sausage processing to substitute chemical preservatives.

\section{REFERENCES}

Abd El-Salam, M.A. (1978): Chemical and technological studies on some Egyptian meat. Mvsc., Thesis, Fac. Agri., El- Azhar Univ.

Ali, F.H.; Kassem, G.M. and Atta-Alla, O.A. (2010): Propolis as a natural decontaminant and antioxidant in fresh oriental sausage. Vet. Italiana J., 46(2): 167-172.

APHA (1992): Compendium of Methods for the Microbial Examination of food. $3^{\text {rd }}$ Ed., American public health association, Washington, Dc., USA.

Ashour, Azza, T. (1989): Studies on propolis gathering with special reference to its antimicrobial properties. Thesis, Ph.D.Fac. Agri. Cairo Univ.

Assegid, G.; Erik, S. and Ingolf, L. (2004): Microbiological and calorimetric investigations on the antimicrobial actions of different propolis extracts: an in vitro approach. Thermochimica Acta, 422, (1-2): 115.

Bankova, V.S.; Popov, S.S. and Marekov, N.L. (1989): Isopentenyl cinnamates from poplar buds and propolis. Phytochemistry 28: 871873.

Bankova, V. and Marcucci, M.C. (2000): Standardization of propolis: present status and perspectives. Bee World, 8(4): 182-188.

Banskota, A.H.; Tezuka, Y. and Kadota, S. (2001): Recent progress in pharmacological research of propolis. Phytotherapy Research, 15: 561-571.

Be-Jen, W.; Hui-Iien, Y. and Ran, Y.Z. (2003): Supercritical fluid extractive fraction study of the antioxidant activities of propolis. J. Food Chem. 237.

Biscaia, D. and Ferreira, S.R.S. (2009): Propolis extracts obtained by low pressure methods and supercritical fluid extraction. J. of Supercritical Fluids, 51: 17-23.

Bonvehi, J.; Coll, F. and Jorda, R. (1994): The composition, active components and bacteriostatic activity of propolis in dietetics. $\mathrm{J}$. of American Oil Chemists' Socity 71(5): 529-532.

Burdock, G.A. (1998): Review of the biological properties and toxicity of bee propolis (propolis). Food and Chemical Toxicology, 36: 347-363.

Cihangir, N.; Sorkun, K. and Salih, B. (2005): Chemical composition and antibacterial activities of propolis collected from different regions of Turkey. Hacettepe Journal of Biology and Chemistry34: 59-67.
Contreras-Castillo, C.J.; Bernardi, S.; Golineli, B.B.; Favaro-Trindade, C.S.; Cavenaghi, A.D.; Harada, M.M. and Beraquet, N.J. (2009): Addition of microencapsulated propolis to dry fermented sausage. $55^{\text {th }}$ International congress of Meat Science and Technology, Copenhagen, Denmark.

Costa Campos, V.A.; dos Santos Jùnior, H.M.; Olivera, D.F.; Pereira de Carvaiho, H.W.; Teixeira Machado, A.R. and Tirelli, A.A. (2011): Antibacterial activity of propolis produced by Frieseomelittavaria. Ciênc. Agrotec., Lavras, 35(6): 1043-1049.

Cowan, M.M. (1999): Plant products as antimicrobial agents. Clinical Microbiological Review, 12(4): 564-582.

DeCastro, S.L. and Higashi, K.O. (1995): Effect of different formulations of propolis on mice infected with Trypanosoma cruzi. J. Ethnopharmacol 46: 55-58.

Dessouki, T.; El-Dashlouty, A.; El-Ebzary, M. and Heikal, H. (1980): Propolis and some other natural antioxidants for fats of frozen meat. Agricultural Res. Review, 58 (3): 311-320.

Dobrowolski, J.W.; Vohora, S.B. and Sharma, K. (1991): Antibacterial, antifungal, antiamoebic, anti-inflammatory and antipyretic studies on propolis bee products. J Ethnopharmacology 35: 77-82.

El-Bassiony, T.A.; Saad, N.M. and El-Zamakan, M.A. (2012): Study on the antimicrobial activity of Ethanol Extract of Propolis against enterotoxigenic Methicillin - Resistant Staphylococcus aureus in Lab prepared Icecream. Vet. World, 5(3): 155-159.

El-Dieb, S.M. and Abd Al-Fattah, A.M. (1997): The antibacterial and antifungal effect of honey bee propolis and its use on Ras cheese. Bull. Fac. Agri. Cairo Univ., 48: 95-103.

ESS (1991): Egyptian Organisation for Standardisation and Quality Control. Egyptian Organisation for Standard specifications for frozen sausage (1972).

FAO (1986): Food and Agriculture Organization. 8. Food analysis. In Manuals of food quality control (P.G. Martin, ed). Food and Nutrition Paper 14/5, Rome, 248.

Grange, J.M. and Davey, R.W. (1990): Antibacterial properties of propolis (bee glue). J Royal Society of Medicine, 83: 159-160.

Greenaway, W.; Scaysbrook, T. and Whately, F.R. (1990): The composition and the plant origins of propolis. A report of work at Oxford. Bee World, 71(3): 107-118.

Greenaway, W.; May, J.; Scaysbrook, T. and Whatley, F.R. (1991): Identification by gas chromatography-mass spectrometry of 150 compounds in propolis. ZeitschriftfürNaturforschung, Teil 46C: 111-121. 
Haddadin, M.S.Y.; Nazer, I.; Abu Raddad, S.J. and Robinson, R.K. (2008): Effect of propolis on two bacteria species with probiotic potential. Pakistan J. Nutrition, 7: 391-394.

Han, S.K. and Park, H.K. (1995): A study on the preservation of meat products by natural propolis: effect of EEP on protein change of meat products. Korean J. Animal Sci.: 37: 551-557.

Han, S.K. and Park, H.K. (2002): Accumulation of thiobarbituric acid - reactive substances in cured pork sausages treated with propolis extracts. J. Sci Food Agric, 82: 148.

Han, S.K.; Yamauchi, K. and Park, H.K. (2001): Effect of nitrite and propolis preservative on volatile basic nitrogen changes in meat products. Microbios, 105(411): 71

Harold, E.; Kirk, R.S. and Sawgh, R. (1981): Person Chemical analysis of food. $8^{\text {th }}$ ed. Longman Group Limited, New York, London.

Hašcik, P.; Garlik, J.; Elimam, I.O.E.; Kac àniova, M. and Benczovà, E. (2011): Sensory quality of poultry meat after propolis application. Microbiol., Biotechnol. And Food Science J., 1(2): 172-186.

Hayashi, K.; Komura, S.; Isaji, N. and Ohishi, N. (1999): Isolation of antioxidative compounds from Brazilian propolis. Chemical and pharmaceutical Bulletin, 47 (11): 1521.

Hegazi, A.G. (2000): Propolis an overview. Congreso Internacional de Propóleos, 1-2 September 2000, Buenos Aires, Argentina. http://www.apinetla.com.ar/congreso/c05.pdf

Hegazi, A. and Abd El-Hady, F.K. (2001): Egyptian propolis: antimicrobial activity and chemical composition of Upper Egypt propolis. Znaturforsch., 56 (1-2):82.

Hegazi, A. and Abd El-Hady, F. (2002): Egyptian propolis: Antioxidant, antimicrobial activities and chemical composition of propolis from reclaimed lands. Naturforsch., 57(3-4): 395.

Hemeida, H. and Kobeassy, M. (2002): Chemical composition and active components of Egyptian honeybee propolis as a natural substance for preservation of bastrami. J. Agric. Sci. Mansoura Univ., 28 (5): 3747.

International Food Information Service. (2005): IFIS dictionary of food science and technology. Shinfield. FL: International Food Information Service (IFIS Publishing)/ Blackwell Publishing. 157.

Isla, M.I.; Nieva, M. and Sampietro, A.R. (2001): Antioxidant activity of Argentine propolis extracts. J. Ethnopharmacol 76: 165-170.

Kalogeropoulos, N.; Konteles, S.J.; Troullidou, E.; Mourtzinos, I. and Karathanos, V.T. (2009): Chemical composition, antioxidant activity and antimicrobial properties of propolis extracts from Greece and Cyprus. Food Chemistry: $116,452-461$.

Kartal, M.; Ylldız, S. and Kaya, S. (2003): Antimicrobial activity of propolis samples from two different regions of Anatolia. J. Ethnopharmacol 86: 69-73.

Kilic, A.; Baysallar, M.; Besirbellioglu, B.; Salih, B.; Sorkun, K. and Tanyuksel, M. (2005): In vitro antimicrobial activity of propolis against methicilline-resistant $S$. aureus and vancomycin- resistant Enterococcus faecium. Annals of Microbiol., 55: 113-117.

Lu, L.C.; Chem, Y. and Chou, C. (2005): Antibacterial activity of propolis against Staphylococcus. Int. J. Food Microbiol. 15, 102 (2): 213.

Marcucci, M.C. (1995): Propolis: Chemical composition, biological properties and therapeutic activity. Apidologie, 26 (2): 83-99.

Marquele, F.; Stracieri, K.; Fonseca, M. and Freitas, L. (2006): Spray-dried propolis extract: Physicochemical and antioxidant properties. Pharmazie, 61 (4): 325.

Mohamed, Manal M. (2002): Quality improvement of some Egyptian frozen meat products. Ph.D. Thesis, Fac. Vet. Med. Cairo, Univ.

Nagai, T.; Inoue, $R$. and Suzuki, N. (2003): Preparation and antoxidant properties of water-extract of propolis. J. Food Chem. 29-33.

Naydenski, H.; Muli, E. and Bankova, V. (2010): New biologically active compounds from Kenyan propolis. Fitoterapia, doi: 10.1016/ j.fitote. 01.007.

Nouman, T.; El-Nawawy, F.A.; El-Ashmawy, A.M. and Sorur, A. (1982): The microbial association in cool-stored fresh sausage. Assiut Vet., Med., J., 10(19): 137.

Olivant, J.M. (1957): An introduction to laboratory methods in veterinary food control. Published by Dep. of vet. Pathol., Liverpool, Univ. England .

Pahsa, C.; Sayeed, S. and Ali, M.S. (2009): Antisalmonella activity of selected medicinal plants. Turkish Journal of Biology 33: 59-64.

Petrova, A.; Popova, M.; Kuzmanova, C.; Tsvetkova, I.; Naydenski, H.; Muli, E. and Bankova, V. (2010): New biologically active compounds from Kenyan propolis. Fitoterapia, doi: 10.1016/j.fitote. 01.007.

Popova, M.; Bankova, V. and Tsvetkova, I. (2001): The first glycosides isolated from propolis diterpenerhamnosides. Z Naturforsch. C-J Biosci 56: 1108-1111.

Raghukumar, R.; Vali, L.; Watson, D.; Fearnley, J. and Seidel, V. (2010): AntimethicillinResistant S. aureus (MRSA) Activity of 'Pacific Propolis' and Isolated Prenylfl 
avanones. Phytother. Res. (www.interscience. wiley.com) DOI: 10.1002/ptr.3096.

RodriguezVaquero, M.J.; AredesFernàndez, P.A. and Manca de Nadra, M.C. (2011): Effect of phenolic compound mixtures on the viability of Listeria monocytogenes in meat model. Food Technolo. and biotechnol. J., 49 10: 83-88.

Said, S.; Khan, S.; Ahmad, I. and Ali, H. (2006): Chemical composition of Egyptian and UAE propolis. J. Pharm. Sci. 19(1): 58.

Salatino, A.; Teixeira, E.W.; Negri, G. and Message, D. (2005): Origin and chemical variation of Brazilian propolis. Evidence-based Complementary and Alternative Medicine, 2: 33-38.

Silva, M.S.S.; De Lima, S.G.; Oliveira, E.H.; Lopes, J.A.D.; Chaves, M.H.; Reis, F.A.M. and L. Citó, A.M.G. (2008): Anacardic acid derivatives from Brazilian propolis and their antibacterial activity. Ecl. Quim.,Săo Paulo, 33:53-58.

Sforcin, J.M.; Fernandes, A. and Lopes, C.A.M. (2000): Seasonal effect of Brazilian propolis antibacterial activity. J Ethnopharmacol 73: 234-249.

Sforcin, J.M. (2007): Propolis and the immune system: A review. J. Ethnopharmacology, 113:1-14.

Shahidi, S. and Wanasundara, B.K. (1992): Phenolic antioxidants. C.R.I.T. Rev. Food Sci. Nur. 32: 67.
Sorkun, K.; Süer, B. and Salih, B. (2001): Determination of chemical composition of Turkish propolis. ZNaturforsch 56: 666-668.

Temiz, A.; Sener, A.; T, Ö.A.; Sorkun, K. and Salih, B. (2011): Antibacterial activity of bee propolis samples from different geographical regions of Turkey against two foodborne pathogens, Salmonella entritidis and Listeria monocytogenes. Turk. J. Biol., 35: 503-511.

Tosi, E.A.; Ré, E.; Ortega, M.E. and Cazzoli, A.F. (2007): Food preservative based on propolis: Bacteriostatic activity of propolis polyphenols and flavonoids upon E.coli. Food Chemistry 104: 1025-1029.

Trusheva, B.; Popova, M.; Bankova, V.; Simova, S.; Marcucci, M.; Miorin, P.; Pasin, V. and Tsvetkova, I. (2006): Bioactive Constituents of Brazilian Red Propolis. Evid Based Complement Alternat Med., 3(2): 249. Published online doi: 10.1093/ecam/nel006. Published by Oxford University Press.

Uzel, A.; Sorkun, K. and Önçă̆, Ö. (2005): Chemical compositions and antimicrobial activities of four different Anatolian propolis samples. Microbiol Res 160: 189-195.

Wong, J.W.; Hashimoto, K. and Shipamoto, $T$. (1995): Antioxidant activities of rosemary and sage extracts and vitamin $\mathrm{A}$ in model meat system. J. Agric. Food Chem. 43: 2707.

\section{إستخدام مستخلص صمغ العسل كمحاولة لزيادة فترة الصلاحية وتحسين معايير جودة

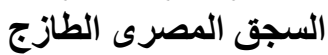

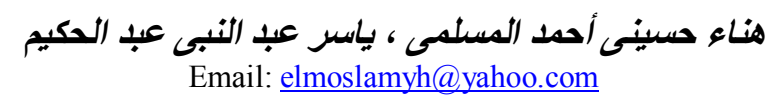

نم عمل هذا البحث لتقييم تأثيثير مستخلص صمغ العسل على معايير الجودة المختلفة للسجق المصرى البقرى الطازج و علالتتة بطول

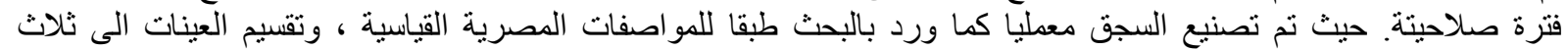

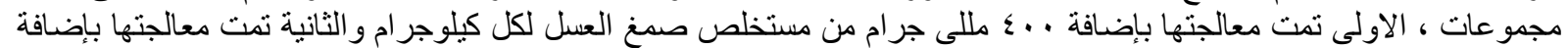

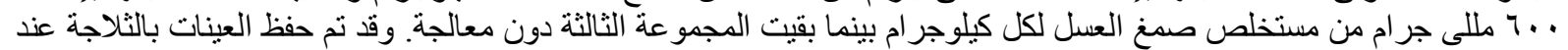

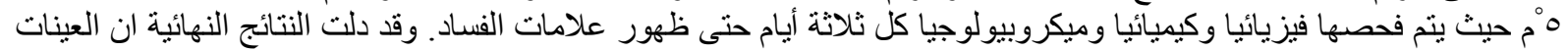

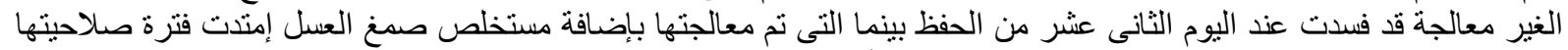

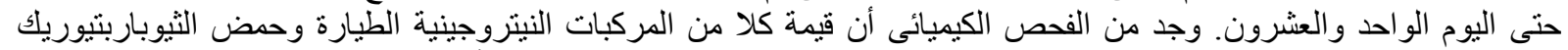

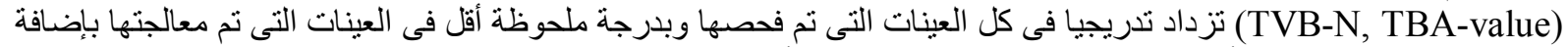

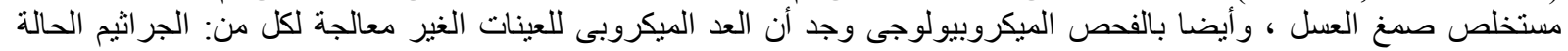

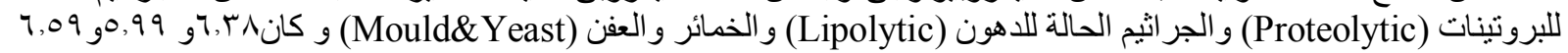

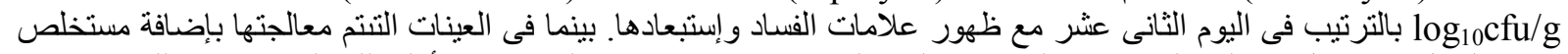

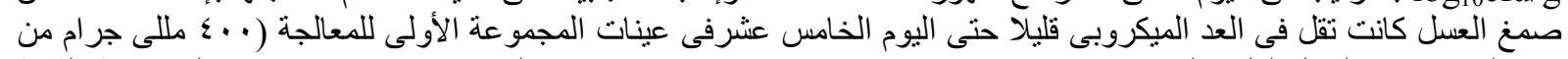

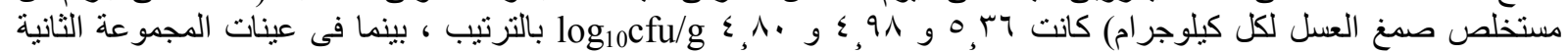

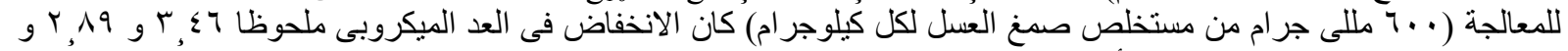

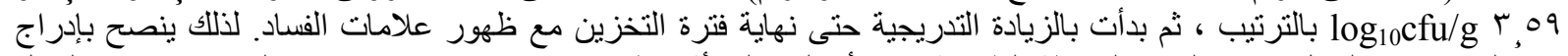

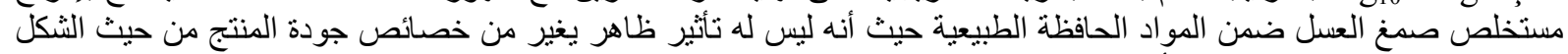
و الطعم بالنسبة للمستهلك بينما له تأثير و اضح فى إطالة مدة الصلاحية. 